\title{
Competition Principles and Vertically Integrated Utilities
}

\section{Chloe Weiter}

$\mathrm{R}$ estructuring of utility industries in Australia has been underway since the early 1990s in response to the National Competition Policy reform process. The process commits Commonwealth, State and Territory Governments to a number of initiatives, including structural reform of public utilities and providing open access to significant infrastructure facilities that meet criteria specified in the Competition Principles Agreement (National Competition Council, 1995). Essential to this process was the addition of Part IIIA to the Trade Practices Act 1974 (TPA), which facilitates a regime for open access to essential infrastructure facilities.

Western Australia is a signatory to the reform process, initiated restructuring of its electricity industry in the early 1990s, and has had an open access regime in place since 1997 which enables Independent Power Producers (IPPs) to access the transmission and distribution network of the State-owned utility (Western Power). Vertical disaggregation of the industry has not yet occurred, and Western Power is largely responsible for developing, administering and regulating the access regime, as well as being the dominant generator and retailer in Western Australia. It has been argued that the existing open access regime (particularly its lack of an independent regulator) supports the dominant position of Western Power and has not led to increased competition.

In January 2001 one IPP sought a ruling under Part IIIA that would require access arrangements to be negotiated through independent arbitration rather than through the existing access regime. In response, Western Power argued that electricity networks in a vertically integrated utility are an integral part of the production process and therefore beyond the jurisdiction the TPA. The two parties reached a negotiated settlement which prevented a judicial testing of Western Power's claims about the electricity production process which bring into question the cornerstone of the open access regime with respect to the electricity industry. It thus leaves open a larger question of whether Part IIIA can deal adequately with open access in an industry, such as electricity, where the essential facility cannot be clearly identified, and the services provided by it cannot be clearly separated from other parts of the industry.

This paper examines the reform process and the importance of Part IIIA of the TPA. It uses a Western Australian case study to discuss the usefulness of this part of the legislation and suggests that the case put forward by Western Power

Chloe Weiter is a PhD student at the Murdoch Business School, Murdoch University, Western Australia. She is supported by an Australian Cooperative Research Centre for Renewable Energy Postgraduate Research Scholarship. 
represents a direct challenge to the applicability of the Competition Principles Agreement and Part IIIA to electricity networks. It also suggests that the State Government has, to date, been ineffectual in its restructuring of the electricity sector, completing only part of the task and leaving IPPs frustrated in their attempts to compete against, and contract with, the utility. The State Government, however, established the Electricity Reform Task Force (ERTF) in late 2001, which has provided recommendations to Government regarding further restructuring of the electricity industry, and these recommendations may lead to changes in the access arrangements (ERTF, 2002a).

The paper is organised as follows. First, it reviews the Australian reform process and describes the three avenues for achieving access to essential infrastructure facilities under Part IIIA. It then outlines the reform process that has occurred in Western Australia and describes the background to the disputes between Western Power and the IPP. It concludes with some comments on the applicability of Part IIIA to electricity networks and arguments against vertical integration in an open access environment.

\section{Background}

Reform of Government Business Enterprises is part of the broader National Competition Policy designed to improve the productivity and international competitiveness of Australia's firms and institutions. The need for a national competition policy was agreed on by the Council of Australian Governments, which established an Independent Committee of Inquiry (1993), chaired by Professor Hilmer, to report on the reforms necessary to give effect to the policy. Major recommendations of the Inquiry (Hilmer Report) were incorporated in the Competition Principles Agreement 1995 and enacted in the National Competition Policy Reform Act 1995 - an amendment to the TPA. The Competition Principles Agreement commits Western Australia, the other States and Territories, and the Commonwealth to a common set of competition laws and policies including the principles of competitive neutrality, structural reform of public monopolies and providing third-party access to significant infrastructure facilities.

Oversight of National Competition Policy is provided by the National Competition Council (NCC) which advises on design and coverage of access rules under the national access regime and makes recommendations concerning whether an access declaration should be made under Part IIIA. Access rules are regulated by independent, generic regulatory bodies at the Federal and State levels (Outhred, 2001). The Australian Competition and Consumer Commission (ACCC) is the Federal body responsible for policing the TPA. Jurisdiction of competition laws in the TPA is vested with the Federal Court of Australia.

With respect to open access to essential infrastructure, the Hilmer Report recommended that the TPA be amended to incorporate a regime for access to essential infrastructure facilities and, in response, Part IIIA was added to the TPA in 1995. Part IIIA establishes a national access regime for significant infrastructure facilities and sets out three pathways for achieving access: 
certification as an effective regime, undertakings, and declaration. Details of each pathway are provided in the next section.

The Productivity Commission (2001) recently reviewed the National Access Regime. Among other issues, the review discusses vertical integration and the potential role that the claim of a production process might play in avoiding a declaration. The review recommends that a production process should continue to be exempt from the national access regime, but that the NCC should monitor any developments of its use. Should any judicial interpretation lead to outcomes that detract from efficiency, the review suggests 'it may be necessary to remove the exemption or clarify its intent' (p. 154).

\section{Third Party Access to Essential Services}

As part of the National Competition Policy framework, Part IIIA establishes a national access regime for achieving access to use the services of a range of essential infrastructure facilities. The Hilmer Report (1993:240) defines an 'essential facility' as a facility that cannot be duplicated economically, and cites electricity transmission grids, rail tracks and airports as examples. Part IIIA, on the other hand, does not define 'essential facility', instead relying on limitations placed on the definition of the term 'service'. A 'service' is defined in S44B (Part IIIA) as a service provided by means of a facility and includes the use of an infrastructure facility such as a road or railway line, handling or transporting things such as goods or people, and a communication service or similar service. It does not include the supply of goods, the use of intellectual property, or the use of a production process, except to the extent that it is an integral but subsidiary part of the service.

Under Part IIIA, there are three pathways to access essential infrastructure facilities: certification as an effective regime, undertakings, and declaration, (NCC, 2001). Each one is described below.

\section{Certification as an effective regime}

This mechanism, set out in S44M and S44N (Part IIIA), gives State and Territory Governments the opportunity to establish their own access regimes and have them certified as effective. When a State or Territory introduces an access regime, the responsible Minister may apply to the NCC to seek a decision by the Commonwealth Minister that the regime is effective. The NCC makes a recommendation to the Commonwealth Minister based only on the relevant principles set out in the Competition Principles Agreement. If the NCC decides that the regime meets the criteria for an effective regime, it is certified by the Minister. Once certified, the effective regime determines the terms and conditions of access. A number of State access regimes under the National Gas Code have been certified as effective regimes through this mechanism. 


\section{Undertakings}

An undertaking allows a network service provider to give an access undertaking to the ACCC specifying the terms on which access will be made available to third parties. The ACCC assesses the undertaking as described under S44ZZA (Part IIIA) and is required to decide whether or not to accept the undertaking after a public consultation process. In its assessment, the ACCC is required to consider the legitimate business interests of the provider, the public interest, the interests of the person who might want access, whether the facility is already the subject of an access regime and any other matters which the ACCC thinks relevant. If the undertaking is accepted by the ACCC, the undertaking determines the terms and conditions of access for all third parties. The regime governing access to the National Electricity Market (NEM) operates as an industry code approved as an undertaking through this process.

\section{Declaration}

Declaration, the process relevant to the discussion in this paper, provides third parties (individuals, businesses, or a designated Minister) with an avenue through which they can apply to the NCC to have a facility declared an essential facility. A third party seeking a declaration can do so if they are not satisfied that the existing open access regime is fair. A declaration may be sought when the regime has not been certified effective and an undertaking has not been accepted using one of the two processes described above. That is, a network service provider has chosen not to seek an undertaking, and the responsible State or Territory Minister has not sought to have the regime certified as effective, or when either of these pathways has been pursued and has resulted in the rejection of an access regime.

Declaration involves a third party making a written application to the NCC for a declaration that a facility is an essential facility. The NCC assesses the application under S44G (Part IIIA) considering a number of criteria including the promotion of competition, the existing access arrangements, safety and the public interest (NCC, 2001). The NCC makes a recommendation to the designated Minister, who then declares the facility or decides not to declare it. If it is declared, the third party and the network service provider are required to try to negotiate terms and conditions of access. Failure to reach agreement through negotiation will see the terms and conditions determined through legally binding arbitration by the ACCC.

In Western Australia, a third party power producer sought a declaration from the NCC which, had it been successful, would have seen Western Power's transmission and distribution network declared an essential facility. The process, however, was challenged by Western Power in the Federal Court of Australia. In its defence, Western Power claimed that the transmission and distribution network is an integral component of its production process and thus not within the scope of Part IIIA. 


\section{The Reform Process in Western Australia}

Western Australia is part of the national reform process but its geographical isolation from the eastern States' National Electricity Market (NEM) enables it to undertake electricity industry restructuring at its own pace. Restructuring of the energy sector in Western Australia has been underway since the early 1990s, following recommendations by the Energy Board of Review (1993). In 1995, the then State Energy Commission of Western Australia (SECWA) was split into corporatised gas (AlintaGas) and electricity (Western Power) utilities. AlintaGas has since been further disaggregated, and privatised, while Western Power remains in State Government hands as a vertically integrated monopoly. A recent report by the ERTF has recommended vertical disaggregation of Western Power (ERTF, 2002a).

An open access regime for Western Power's transmission and distribution networks, based on compulsory bilateral contracting between the generator and each of its customers, with half-hourly balancing between energy generated and energy consumed, has been in place since 1997. The regime is developed and administered by Western Power while the Minister for Energy has progressively lowered access levels. The State Government, through the responsible Minister, has not sought to have the regime certified as an effective regime, nor has Western Power sought to have an access undertaking accepted.

The situation in Western Australia contrasts with developments in the rest of the country. The vertically integrated utilities in the eastern states were disaggregated prior to joining the NEM. The National Electricity Code under which NEM participants operate has been accepted by the ACCC through an undertaking. In Tasmania vertical disaggregation has occurred and, while the open access regime has not been certified, Tasmania is set to join the NEM pending the construction of an undersea cable and from that time will operate under the National Electricity Code. In the Northern Territory, Power and Water remains a vertically integrated utility. Open access to the transmission and distribution network is provided through the Electricity Network (Third Party Access) Code, the undertaking for which was accepted by the ACCC in March 2002 (NCC, 2002). Importantly, an independent regulator has been appointed with powers to regulate the transmission and distribution business, but it may take several years before the effectiveness of this regime can be determined.

Introducing an effective access regime to an integrated monopoly in most industries is difficult, even with an independent regulator, because it assumes that something called a 'transmission service' can be unbundled and priced separately from the rest of the industry. This open access model fails to recognise the importance of an independent system operator that is responsible for coordination of both production and transportation assets. In a vertically integrated industry, entities associated with the network operations will have, or will be perceived to have, an unfair competitive advantage unless a regulator steps in to tip the balance in the other direction. In the electricity industry, it creates the additional problem 
of trying to define and price all the interactions between independent network users and a utility's own operations (Ruff, 1996).

In Western Australia, IPPs and industry commentators complain that the open access regime is ineffective and that it has not led to effective competition in the industry (Perth Energy, 2000; Booth, 2000:134). Certainly, to date, no private plant has been developed specifically to sell power to contestable customers. In its second discussion paper, the ERFT (2002b) drew attention to the perceived deficiencies of the current access regime, and cited the application to the NCC for a declaration as evidence of them.

Three proponents, Normandy Power Pty Ltd, NP Kalgoorlie Pty Ltd, and Normandy Golden Grove Operations Pty Ltd (Normandy Power et al.) sought a declaration of the transmission and distribution network that would have given them the legal right to negotiate access conditions and, if necessary, to have access conditions determined by legally binding arbitration through the ACCC. The background to the declaration is outlined in the next section.

\section{The Parkeston Power Station and Normandy Power}

With its construction facilitated by a State Agreement, the Goldfields Gas Pipeline Agreement Act 1994, the Goldfields Gas Pipeline brought with it a number of associated developments. To enable these developments, the State Agreement included provisions to allow the owners of the Goldfields Gas Pipeline to sell electricity to their own affiliated companies using the Western Power network. Also included was a provision that enabled the Minister for Resources Development to approve customers who would then be permitted to purchase electricity from the supplier of their choice.

The Parkeston Power Station is an example of an infrastructure development that was facilitated by the construction of the gas pipeline and the associated State Agreement. Commissioned in 1996, it is located near Kalgoorlie at the end of a long feeder line. It is owned by Goldfields Power, an associated company of Normandy Power. Normandy Power purchases the major portion of the output for supplies to its customers, while Goldfields Power markets the remaining output to contestable customers (Normandy Power et al., 2001).

There were certain technical difficulties associated with the proposed method of interconnection of the Parkeston Power Station, related to the low inertia of the turbines, and suggestions that interconnection would result in instability in the State's electricity network (Hansard, 1998:4097). These technical issues might have been avoided had there been an environment in which there could have been constructive discussion between the Normandy group of companies and Western Power prior to their decision to purchase the turbines. It seems that the Normandy group of companies were reluctant to reveal their plans to a major competitor at an early stage in the project evaluation, and purchased turbines that Western Power was subsequently reluctant to connect to its network.

Despite the technical hurdles, Normandy Power and Western Power reached an Interim Access Agreement (IAA) in October 1996, which was facilitated by the 
Goldfields Gas Pipeline Agreement Act 1994. The IAA entitled Normandy Power to export up to $15 \mathrm{MW}$ of electricity from the Parkeston Power Station to their remote loads at specified locations in the Kalgoorlie area and to purchase or deliver up to 35 MW of standby power (Normandy Power et al., 2001).

\section{An Environment of Distrust}

The application for declaration of the transmission and distribution network was the third in a number of legal disputes between Western Power and the Normandy group of companies. These disputes have been settled through a negotiated process between the two parties, which brings to a conclusion the specific issues discussed below. Details of the settlement are confidential. Thus there will be no judicial outcome for any of the legal actions. However, some implications remain to be resolved about the applicability of Part IIIA of the TPA to electricity networks.

The first dispute related to the IAA between Western Power and Normandy Power. Western Power (2001) claimed that the terms and conditions provided under the IAA were on an interim basis pending the introduction of the general open access regime and, in 2000, sought to enter into negotiations with Normandy Power regarding future access. An outcome to the negotiations was not reached and Western Power sought to terminate the IAA, which would have forced Normandy Power to seek access to the network under the regulations applying to the general open access regime. Legal proceedings were brought by Western Power against Normandy Power in which Western Power sought a declaration that the IAA had been validly terminated or was otherwise at an end with effect from 20 January 2001. The case was heard in August 2001 and the Supreme Court of Western Australia ruled in favour of Western Power. In his ruling, McKechnie J (2001) concluded that the IAA was intended to be a bridging agreement until such time as the general open access regime was applicable to Normandy Power. He determined that it had been applicable to Normandy Power since 1 July 1997, quoting the then Minister for Energy who announced (Barnett, 1996, cited in McKechnie J, 2001:point 53) that open access would be provided

... for all consumers with an average load exceeding 10MW at a single point, as well as consumers who are approved under law to receive electricity from other than Western Power on another site (i.e. Normandy Power under the Goldfields Agreement Act).

As such, McKechnie J (2001) declared that the IAA had been validly terminated. Normandy Power appealed the decision.

In the second case, Normandy Power et al. (2001) claimed that during the period of negotiation of the IAA, Western Power contracted those customers permitted to purchase electricity from the supplier of their choice at a reduced tariff, thus breaching the provisions of 546 of the TPA. They also claimed that Western Power abused its market power and was involved in misleading and 
deceptive conduct. These allegations were the subject of a legal action by Normandy Power, Normandy Pipelines and NP Kalgoorlie in the Federal Court of Australia. The case was expected to be heard in late 2002 .

These two cases give an indication of the environment of distrust that had developed, culminating in the application for declaration of Western Power's transmission and distribution network. Details of the application for declaration are discussed below.

Two classes of contestable customers, those approved under the Goldfields Gas Pipeline Agreement Act 1994 and those approved under the general open access regime, can be sold power by Goldfields Power and Normandy Power using the open access regime described above. The Normandy group of companies, however, were of the view that the general open access regime was not fair because of unreasonable technical limitations placed on IPPs, limited scope for negotiation and dispute resolution, the lack of an independent regulator, inadequate ring fencing arrangements within Western Power, and because the regime hinders the access seeker from gaining access (Normandy Power et al., 2001). Accordingly they sought a declaration from the NCC that the transmission and distribution services of Western Power be given the status of declared services under S44G (Part IIIA).

On 9 January 2001, the NCC accepted an application for declaration of Western Power's transmission and distribution networks from Normandy Power, NP Kalgoorlie and Normandy Golden Grove. The applicants claimed that Normandy Power had entitlements under the Goldfields Gas Pipeline Agreement Act 1994 and the general open access regime to supply specified customers, while NP Kalgoorlie and Normandy Golden Grove had entitlements under the general open access regime to access the network. They maintained that neither the IAA nor the open access regime provided effective means to access the Western Power network. The future of the IAA was not assured because of the ruling by McKechnie J, and they asserted that the general open access regime was not effective because of its terms and conditions, the ring-fencing arrangements within Western Power, an unfair past capital contributions policy, the absence of an independent regulator, an inadequate negotiation framework, and the lack of enforceable dispute resolution (Normandy Power et al., 2001).

The NCC released a discussion paper outlining the NCC's preliminary consideration of the application against each of the declaration criteria and called for written submissions from interested parties to assist in assessing the application (NCC, 2001). Eleven responses were received, mostly in support of the applicants. Western Power's submission, however, took a different view. It made the claim that the transmission and distribution network is an integral component of its production process and thus beyond the scope of the Part IIIA. Details of Western Power's submission are discussed in the following section.

Table 1 provides a summary of the relevant legal challenges between Western Power, the Normandy group of companies and the NCC. 
Table 1 Summary of Relevant Legal Challenges Between Western Power, the Normandy Group of Companies and the NCC

\begin{tabular}{|l|l|l|l|l|}
\hline \multicolumn{1}{|c|}{ Defendant } & \multicolumn{1}{|c|}{ Plaintiff } & \multicolumn{1}{c|}{ At issue } & Court/Council & \multicolumn{1}{c|}{ Status } \\
\hline $\begin{array}{l}\text { Western } \\
\text { Power }\end{array}$ & $\begin{array}{l}\text { Normandy } \\
\text { Power }\end{array}$ & $\begin{array}{l}\text { Breaches of } \\
\text { the TPA }\end{array}$ & $\begin{array}{l}\text { Federal Court } \\
\text { of Australia }\end{array}$ & Negotiated settlement \\
\hline $\begin{array}{l}\text { Western } \\
\text { Power }\end{array}$ & $\begin{array}{l}\text { Normandy } \\
\text { Power et al }\end{array}$ & $\begin{array}{l}\text { Declaration } \\
\text { of access } \\
\text { regime }\end{array}$ & $\begin{array}{l}\text { National } \\
\text { Competition } \\
\text { Council }\end{array}$ & Negotiated settlement \\
\hline $\begin{array}{l}\text { Normandy } \\
\text { Power }\end{array}$ & $\begin{array}{l}\text { Western } \\
\text { Power }\end{array}$ & $\begin{array}{l}\text { Termination } \\
\text { of the IAA }\end{array}$ & $\begin{array}{l}\text { Supreme } \\
\text { Court of } \\
\text { Western } \\
\text { Australia }\end{array}$ & $\begin{array}{l}\text { Judgement in favour of } \\
\text { Western Power. } \\
\text { Appealed by Normandy } \\
\text { Negotiated settlement }\end{array}$ \\
\hline $\begin{array}{l}\text { National } \\
\text { Competition } \\
\text { Council }\end{array}$ & Pestern & $\begin{array}{l}\text { Invalidity of } \\
\text { TPA to open } \\
\text { access regime }\end{array}$ & $\begin{array}{l}\text { Federal Court } \\
\text { of Australia }\end{array}$ & $\begin{array}{l}\text { Will not proceed to } \\
\text { judgement: negotiated } \\
\text { settlement }\end{array}$ \\
\hline
\end{tabular}

Source: McKechnie J, 2001; Normandy Power et al., 2001; Western Power, 2001; 2002.

\section{Western Power's Response}

In response to the application to the NCC, Western Power (2001) initiated proceedings in the Federal Court of Australia which sought a ruling that the service that was the subject of the application is not a service for the purpose of Part IIIA and should therefore not be considered by the NCC.

Western Power considered the definition of a 'service' within the meaning of the term as defined in S44B (Part IIIA) and noted that the applicants defined the 'service' for which they sought a declaration to be 'the transmission of electricity from electricity generators, particularly from the Parkeston Power Station to consumers of electricity in the south-west of WA'. Similarly, they noted that the applicants defined the 'facility' used to provide that service as the 'electrical transmission and distribution systems'.

Western Power argued that the 'facility' (as described above) is unable to function without sufficient generating capacity connected to it, and that without this capacity the transmission and distribution systems would be unable to perform the function of delivering electricity to meet customer loads. Due to the physical properties of electricity and customer quality requirements, Western Power argued that electricity generated by a generation plant is not in a marketable form until it is transformed through a production process, of which the network is a fundamental component. Furthermore, all operations essential to the production of electricity in a marketable form must be continuously available to Western Power, and are an integral, not a subsidiary, part of its production process. Thus, according to Western Power, the Applicants were seeking access to Western Power's production process and not a service as defined in S44B (Part IIIA). 
Western Power cited the case of Hamersley Iron Pty Ltd vs NCC (1999) where the judge found that the use of a rail track to deliver iron ore from mine to port is an 'integral (indeed essential) operation in Hamersley's production process'. The verdict was appealed, but the appeal did not proceed. However, when dismissing the appeal, some matters were dealt with by the Full Federal Court. Specifically, despite the fact that a precedent on the definition of a production process has been set by the decision, the NCC is not obliged to follow it when handling future declaration applications and, furthermore, the decision would not be binding on the Australian Competition Tribunal in relation to appeals against declarations (Productivity Commission, 2001).

Western Power argued that because of the physical constraints of the network, the access being sought is actually a request for Western Power to supply the customers of the applicants with power produced by Western Power. It also quoted the Electricity Transmission Regulations 1996 and the Electricity Distribution Regulations 1997 that transfer all title to, and risk in, electricity within the network to Western Power. Thus any power (or 'good') that is supplied to the applicants' customers, it was argued, belongs to Western Power. It claimed that the 'supply of goods' is what the applicants were requesting. Since the supply of goods is not a subsidiary part of the service provided by the network, the application referred to a supply of goods that is excluded from a 'service' in S44B (Part IIIA), and therefore beyond the scope of the NCC.

Western Power argued that the application was based on the false premise that the network only provides a transmission and distribution service from the Parkeston Power Station to customers. Instead, it claimed (Western Power, 2001:18) 'it is simply not physically possible to use the (network) solely as a means of transmission and distribution as suggested by the Normandy Entities'. It suggested that the following services, which fall outside the scope of Part IIIA, were what the applicants really required:

- the exchange of bulk production of electricity;

- reservation of standby bulk electricity production capacity;

- $\quad$ supply of backup bulk electricity production capacity;

- a billing arrangement between the IPP and customer; and

- an agreed mechanism of charging for the above.

A judicial outcome supporting Western Power would have seen the NCC unable to make a declaration of the facility and would have set a precedent determining Part IIIA as unsuitable for regulating the access regimes for vertically integrated electricity networks. In Western Australia, it would have left IPPs at the mercy of an open access regime developed and regulated by Western Power.

On the other hand, an outcome in favour of the NCC would have allowed the application for declaration to continue. After assessing the application, the NCC would have made a recommendation to the relevant Minister, in this case the Premier of Western Australia, regarding whether to declare the service or not to declare the service. The Premier would have then either declared the service or 
decided not to declare the service. This process would have put the Premier in a potentially awkward situation - acceptance of a NCC recommendation to declare the facility would be an acknowledgment that the existing open access regime (endorsed by the State Government) is ineffective.

\section{Concluding comments}

Although there is not going to be a judicial settlement on these matters, the issues arising from Western Power's proceedings in the Federal Court warrant further consideration. In particular, they raise the following questions.

- Do the provisions in Part IIIA adequately provide for access to essential facilities in the electricity industry?

- Is vertical integration an appropriate structure in an open access environment?

In response to the first question, the validity of Western Power's argument that the electricity transmission and distribution network are parts of a production process needs to be examined. Western Power argued that the electricity industry operates by maintaining a continuous energy conversion process from primary energy forms to end-use energy forms. As part of the energy conversion process, the network conveys electrical energy from power stations to end-use equipment. The flow of electrical energy between generators and end-use equipment is instantaneous. A power station cannot continue to produce electrical energy unless end-use equipment is connected to the network and able to immediately convert the electrical energy to end-use energy forms. Thus, generator, network and end-use equipment are all essential to the satisfactory operation of the electricity industry. However, even with a vertically integrated electricity supply industry, end-use equipment is separately owned by final consumers. This is the case with Western Power. It does not own the end-use equipment, and makes no claim upon it. Therefore, its argument breaks down because it does not have exclusive ownership of the 'production process'. Once independent ownership of end-use equipment is acknowledged, it is inconsistent to claim that independent ownership of power stations is not also possible (Outhred, 2002).

Although Western Power's production process argument is flawed, its claim (Western Power, 2001:18) that 'it is simply not physically possible to use the (network) solely as a means of transmission and distribution' is justified in terms of the physical operation of an electricity network, which is governed by the laws of physics, rather than commercial contracts. An electricity network differs from a road or railway line in that it does not operate by connecting the flow of electricity from the point of production to the point of consumption. Instead, the flow of electricity within the network is dependent on the interaction between all other participants connected to the network. Thus, electricity from a specific generator cannot be directed to a specific load. Although there may be a bilateral contract between a power station and load, that contract has no bearing on the 
actual flow of electricity within the network. The essential tasks of monitoring the actual flows in the system, maintaining system stability and coordinating widely dispersed generators and loads are undertaken by a system operator.

In a vertically integrated utility, the system operator is an integral part of the utility. Using its intimate knowledge of the generators, fuel contracts, the network and loads, the system operator optimises the efficiency of the system. In a disaggregated industry, the system operator is separated out from other components of the industry, to create an independent system operator or, in some instances, one that is integrated with the transmission and distribution business. In either case, the system operator uses bids submitted by participants to optimise the efficiency of the system. In an industry structure, such as that in Western Australia, however, where third parties are permitted to access the transmission and distribution networks of a vertically integrated utility, the system operator is still an integral part of the vertically integrated utility. This creates a potential problem because the system operator may operate, or be perceived to operate, the system in favour of the utility's own generators and customers, and at the expense of third parties. Western Power's open access regime, as well as Part IIIA, fails to recognise that, for a competitive electricity industry to emerge, access to the markets for trading and dealing facilitated through an independent system operator is as essential as access to the network.

The applicability of Part IIIA to an industry where the essential facility cannot be clearly identified, and the services provided by the essential facility cannot be clearly separated from other parts of the industry, is yet to be tested through the judicial process. A judicial outcome in some future situation may prove Part IIIA in its current form inadequate for dealing with open access to essential facilities in the electricity industry. It is possible that only a change in the regulatory arrangements will adequately address open access regimes for essential facilities in the electricity industry.

Western Power's assertion that Part IIIA does not have jurisdiction over its essential infrastructure is unlikely to have direct implications for electricity industries in the rest of Australia. Such a defence is unlikely to be put forward in the NEM where vertical disaggregation has occurred and no participant has an interest in making a case for a production process. In the Northern Territory, the ACCC recently accepted an undertaking for the open access regime, so the declaration process will not be tested. It is too soon to make a judgement on the effectiveness of this regime.

With regard to the second question of vertical integration in an open access environment, the Western Power argument does reinforce the need for the disaggregation of vertically integrated electricity (and other) utilities. The problems that were predicted by Ruff (1996), the testing of the declaration process in relation to electricity transmission and distribution networks, and the other legal challenges within the industry, are unlikely to occur in a disaggregated industry. The Hilmer Report recommendation, and a cornerstone of the Competition Principles Agreement, to disaggregate the functions of vertically integrated utilities, has been vindicated by the difficulties encountered in Western Australia. 
The Hamersley case indicates that vertical integration may have implications for open access in other industries. The Productivity Commission (2001:492) noted that the judgement 'had set too broad a precedent for what constituted a production process' and that 'the decision sent a signal that vertical integration could be used to avoid access claims under Part IIIA'. The negotiated settlement pre-empted a judicial definition of a production process, thus leaving open the opportunity for future use of this argument by vertically integrated utilities.

The Goldfields Gas Pipeline Agreement Act 1994 and the general open access regime gave one IPP reason to believe that it had a right to seek to use the Western Power network to supply customers. Western Power, however, appears to be blocking attempts to have its network access regime brought into line with national policy through the declaration process. The negotiated settlement between the two parties ensures that, for the time being, Western Power will continue to use the current open access regime, and that the regime will not be subject to the process available under Part IIIA.

On the other hand, a victory for the NCC would have seen the application for declaration proceed, and possibly an access regime developed through independent arbitration, but no structural changes to Western Power. Thus, whatever the result of the case (including a negotiated settlement), the outcome for competition in Western Australia's electricity industry would not have been satisfactory in the long term.

The ERTF (2002a) presented recommendations to the State Government in October 2002, and recommended the vertical disaggregation of Western Power, in order to remove the inherent conflict of interest that arises when trying to provide open access to the transmission and distribution component of a vertically integrated utility. On its own, this will not be sufficient to ensure that a fair and non-discriminatory open access regime is established. The ERFT also recommended the development of an open access regime, which the State Government should seek to have certified as effective through the mechanism described in previous sections of this paper. Were this to occur, the electricity industry in Western Australia would be a step closer to fulfilling its obligations under National Competition Policy. But such a step, combined with disaggregation, would not address the question of whether the provisions under Part IIIA are satisfactory to deal with open access to essential facilities in the electricity industry.

\section{References}

Booth, R. (2000), Warring Tribes: The Story of Power Development in Australia, the Bardak Group, Perth.

National Competition Council (1995), Competition Principles Agreement, AGPS, Canberra.

Energy Board of Review (1993), 'The Energy Challenge for the $21^{\text {st }}$ Century: The Report of the Energy Board of Review', Perth. 
Energy Reform Task Force (2002a), 'Electricity Reform in Western Australia: A Framework for the Future', October. http:/www.ertf.energy.wa.gov.au/.

Energy Reform Task Force (2002b), 'Discussion Paper on the Reform of the Electricity Supply Industry in Western Australia', April. http://www.ertf.energy.wa.gov.au/.

Hansard, Western Australian Parliament, (1998), http://www.slp.wa.gov.au/hansard/hans35.nsf/Hansard+Menu/index.html.

Independent Committee of Inquiry (1993), National Competition Policy, AGPS, Canberra.

McKechnie, J. (2001), Western Power Corporation -v- Normandy Power Pty Ltd [2001] WASC 202 (1 August), http://www.austlii.edu.au/.

National Competition Council (2001), 'Application for Declaration of Western Power Corporation Electricity Transmission and Distribution Services: Discussion Paper', February, www.ncc.gov.au.

Normandy Power Pty Ltd, NP Kalgoorlie Pty Ltd, and Normandy Golden Grove Operations Pty Ltd (2001), 'Application for declaration of the Western Power Corporation Electrical Transmission and Distribution Systems in Western Australia', January, www.ncc.gov.au.

Outhred, H. (2001), 'A Review of the Effectiveness of Measures to Support Distributed Generation in Australia', presented to the 'International Symposium on Distributed Generation: Power Systems and Market Aspects', Stockholm, Sweden, June 11-13

Outhred, H. (2002), personal communication.

Perth Energy (2000), 'Electricity Reform in Western Australia's South West Interconnected System', www.perthenergy.com.au.

Productivity Commission (2001), Review of the National Access Regime, Report no. 17, AusInfo, Canberra.

Ruff, L. (1996), 'Stop Wheeling and Start Dealing: Resolving the Transmission Dilemma', pp. 1-24 in M. Einhorn and R. Siddiqu (eds), Electricity Transmission Pricing and Technology, Kluwer Academic Publishers, Norwell, Massachusetts.

Western Power Corporation (2001), 'Submission to the National Competition Council in Response to the Application for Declaration of the Western Power Corporation Electrical Transmission and Distribution Systems in Western Australia by Normandy Power Pty Ltd, NP Kalgoorlie Pty Ltd, and Normandy Golden Grove Operations Pty Ltd', Public Release Version, April, www.ncc.gov.au.

Western Power Corporation (2002), 'Western Power and Newmont Australia Settle Legal Actions', Media Release, 1 August, www.westernpower.com.au.

The author is grateful to Frank Harman, Hugh Outhred, Brian Spalding and two anonymous referees for invaluable input on earlier versions of this work. The work described in this paper has been supported by the Australian Cooperative Research Centre for Renewable Energy (ACRE). ACRE's activities are funded by the Commonwealth's Cooperative Research Centres Program. 